\title{
Pyrolysis oil production from polypropylene plastic waste using molybdenum modified alumina-silica catalysts
}

\author{
Sasiradee Jantasee ${ }^{1, *}$, Natacha Phetyim ${ }^{1}$, Komm Petchinthorn ${ }^{2}$, Tunyahpat Thanupongmanee ${ }^{1}$, and Nuntiporn Sripirom $^{1}$ \\ ${ }^{1}$ Chemical and Materials Engineering Department, Faculty of Engineering, Rajamangala University of Technology Thanyaburi, 12110 \\ Pathum Thani, Thailand \\ ${ }^{2}$ International College, Rajamangala University of Technology Krungthep, 10120 Bangkok, Thailand
}

\begin{abstract}
The production of pyrolysis oil from polypropylene plastic waste was examined over molybdenum modified alumina-silica catalysts $(\mathrm{Mo} / \mathrm{Al}-\mathrm{Si})$. The reactions were carried out with $1 \mathrm{~L}$ of batch reactor under atmospheric pressure at $430{ }^{\circ} \mathrm{C}$. The pyrolysis oil yield was in the order, $10 \% \mathrm{Mo} / \mathrm{Al}-\mathrm{Si}>5 \%$ $\mathrm{Mo} / \mathrm{Al}-\mathrm{Si}>$ the absence of catalyst. The $10 \% \mathrm{Mo} / \mathrm{Al}-\mathrm{Si}$ was highest activity due to the stronger acidity facilitating the pyrolysis reaction. It accelerated the reaction to produce the pyrolysis oil at lower temperature. Comparison of the pyrolysis oil properties to the standards of the diesel fuel from Thai Department of Energy Business shows that the color and the distillation were within standards. Moreover, the results reveal that the kind of raw material affected the product yield of pyrolysis process.
\end{abstract}

\section{Introduction}

Recently, the economic and industrial advance in Thailand have substantially progressed and increased in existence of continuous improvement. With the larger amount of populations, this eventually results in the higher demands of using more resources.

In addition, Thailand has also found the problems of more garbage. Statistics from the Pollution Control Department (PCD) found that in 2017, Thailand has total garbage of 26.6 million tons per year with the average 73,560 tons per day, but only able to eliminate $31.1 \%$ or 8.3 million tons per year. 4.9 million tons were able to recycle and 7.2 million tons were eliminated incorrectly leaving 6.2 million tons of waste remain in the area each year [1]. By moving to landfill and burning them in the hygienic furnace, these two methods can cause both soil and air pollution as a broad environmental problem [2]. Hence, it becomes a government policy to reduce the amount of accumulated waste in local authorities.

The waste to energy technology is investigated to process the potential materials in waste form such as plastic, biomass and rubber tire in an attempt to create the diesel oil for certain purposes [3-5]. Pyrolysis process is one of the options of waste to energy technology to deliver pyrolysis oil to replace fossil fuel $[6,7]$. Its ability to handle unsort and dirty plastic is the main advantage of the pyrolysis process. Furthermore, the process itself does not create toxic or environmental harmful emission unlike incineration.

The products from pyrolysis process have 3 states namely liquid (pyrolysis oil), gas and solid waste [8]. This method will help to decrease the amount of accumulated plastic waste. In fact, it will help to increase the value of the unwanted waste.

This research interested in developing the aluminasilica catalyst that was modified with molybdenum to increase the effectiveness in pyrolysis process of polypropylene plastic waste, in order to produce diesel fuel with equivalent standards.

\section{Experimental}

\subsection{Synthesis of alumina-silica catalyst}

Desired amount of ammonia was added into the deionization water. This solution was mixed with cetyltrimethyl ammonia bromide, and stirred for 30 minutes. Then, $6.3 \mathrm{~g}$ of tetraethyl orthosilicate was added into the mixture and continuously stirred for $1 \mathrm{~h}$. After that the solid was filtered, dried at $120^{\circ} \mathrm{C}$ for $12 \mathrm{~h}$, and calcined at $700{ }^{\circ} \mathrm{C}$ for $6 \mathrm{~h}$ [9].

\subsection{Preparation of molybdenum modified alumina-silica catalyst}

Molybdenum modified alumina-silica catalysts were prepared by an incipient wetness impregnation method. First, ammonium heptamolybdate tetrahydrate at concentration of $5 \%$ and $10 \%$ by weight of molybdenum was dissolved in deionization water. The solution was slowly dropped on the alumina-silica and mixed together. Then, the resulting catalysts were dried at $110^{\circ} \mathrm{C}$ for 12 $\mathrm{h}$, and calcined at $700{ }^{\circ} \mathrm{C}$ for $6 \mathrm{~h}$.

\subsection{Pyrolysis test and product analysis}


The polypropylene plastic waste was collected from the strapping band. $300 \mathrm{~g}$ of raw material was cut into a particle size of $5-7 \mathrm{~mm}$, and added to $1 \mathrm{~L}$ of glass reactor with or without $0.5 \mathrm{~g}$ of the catalysts. The pyrolysis was carried out under atmosphere pressure. The temperature was raised from room temperature to $430{ }^{\circ} \mathrm{C}$. The reaction time was $3 \mathrm{~h}$ after occurring the first drop of pyrolysis oil. The pyrolysis oil and solid waste were weighted for yield percentage calculation. For comparison the pyrolysis oil properties to the diesel fuel standard properties announced by Thai Department of Energy Business, the properties of pyrolysis oil including flash point, viscosity, specific gravity, color value and distillation were tested according to the standards as shown in Table 1.

Table 1. American Society for Testing and Materials (ASTM) standards for testing of fuel oil properties [10].

\begin{tabular}{|c|c|}
\hline Qualification test & Standard \\
\hline Flash point & ASTM D93 \\
\hline Viscosity at $40^{\circ} \mathrm{C}$ & ASTM D445 \\
\hline Color & ASTM D1500-96 \\
\hline $\begin{array}{c}\text { Specific gravity } \\
\text { ASTM D1298 }\end{array}$ \\
\hline $\begin{array}{c}\text { Distillation temperature at } 90 \% \\
\text { recovery }\end{array}$ & ASTM D86 \\
\hline $\begin{array}{c}\text { Cetane index } \\
\text { ASTM D976-06 }\end{array}$ \\
\hline
\end{tabular}

\section{Results and discussion}

\subsection{Effects of molybdenum content on pyrolysis of polypropylene plastic waste}

From Table 2, the products from pyrolysis test have 3 states, liquid, solid and gas. The pyrolysis process of polypropylene plastic waste that did not use catalyst and used catalyst at 5\% and 10\% molybdenum modified alumina-silica catalysts were investigated. The results show percentage of pyrolysis oil were $81.67 \%, 83.65 \%$ and $86.63 \%$ respectively. For the solid waste had percentage yield between 1.38 to $6.31 \%$ by weight, the system that did not use catalyst had the most solid waste of polypropylene plastic as seen in Figure 1.

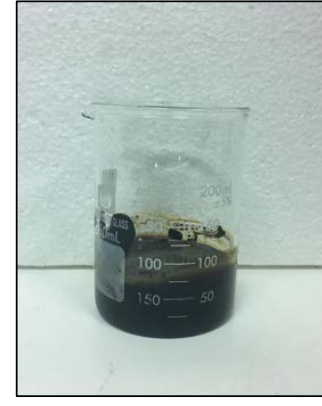

Fig. 1. Solid from the pyrolysis of polypropylene plastic waste without catalyst.

When adding the molybdenum modified aluminasilica catalysts, it resulted in a decreasing in the amount of solid waste. The filling of molybdenum modified alumina-silica catalyst helps to increase a quantity of pyrolysis oil. The percentage of molybdenum modified alumina-silica catalyst by $10 \%$ presented higher percentage of pyrolysis oil than the $5 \%$ molybdenum on alumina-silica catalyst because the more molybdenum added possibly can help to increase the acidity of the catalyst [9]. The pyrolysis process requires a surface catalyst with high acidity properties. Therefore, it is suitable to use this catalyst in the experiment. From the experiment of difference in the use of molybdenum modified alumina-silica catalysts and pyrolysis without catalyst found that the durations of the first drop of oil were different. By increasing the percentage of molybdenum modified alumina-silica catalyst, the result shows the first drop of oil occurring faster than not using catalyst.

Table 2. The pyrolysis of polypropylene plastic waste results.

\begin{tabular}{|c|c|c|c|c|}
\hline \multirow{2}{*}{ Catalysts } & \multicolumn{3}{|c|}{ Yield (\%) } & $\begin{array}{c}\text { Time for } \\
\text { the first oil } \\
\text { drop (min) }\end{array}$ \\
\cline { 2 - 5 } & Gas & $\begin{array}{c}\text { Pyrolysis } \\
\text { oil }\end{array}$ & Solid & 42 \\
\hline No catalyst & 12.02 & 81.67 & 6.31 & 31 \\
\hline $5 \% \mathrm{Mo} / \mathrm{Al}-\mathrm{Si}$ & 13.79 & 83.65 & 2.56 & 28 \\
\hline $10 \% \mathrm{Mo} / \mathrm{Al}-\mathrm{Si}$ & 11.99 & 86.63 & 1.38 & 28 \\
\hline
\end{tabular}

The results of properties test of pyrolysis oil from polypropylene plastic waste are on the Table 3 . It shows that all pyrolysis oil had the color value that met the standard of diesel fuel, less than 7.5. The color of all pyrolysis oils are presented in Figures 2 to 4 . 


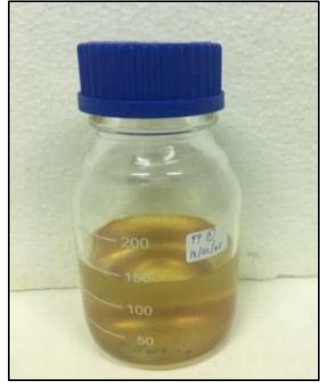

Fig. 2. Liquid from the pyrolysis of polypropylene plastic waste without catalyst.

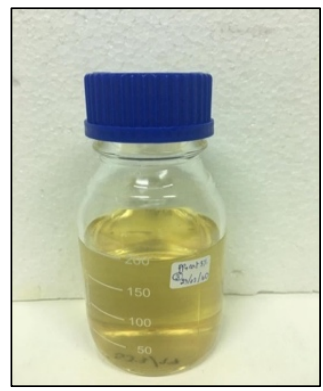

Fig. 3. Liquid from the pyrolysis of polypropylene plastic waste with $5 \%$ molybdenum modified alumina-silica catalyst.

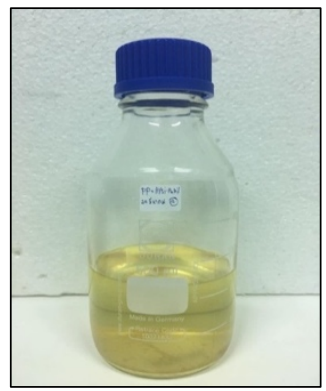

Fig. 4. Liquid from the pyrolysis of polypropylene plastic waste with $10 \%$ molybdenum modified alumina-silica catalyst.

As for specific gravity that nearly reached the standard criteria of diesel oil which had specific gravity of $0.78-0.79$. As for their flash points did not pass the standard criteria of diesel fuel, it depends on the composition of plastic type. Low flash point implied that the pyrolysis oils contained highly volatile materials [11]. Flash point can be improved by removing lighter components from the pyrolysis oils. Simultaneously, the viscosity values of all pyrolysis oils were still lower than the standard, and the distillation value at $90 \%$ recovery passed all of the diesel standard. The cetane index was calculated from the distillation temperature at 50\% recovery and density. The use of catalysts resulted in the decease of cetane index.
Table 3. The properties of pyrolysis oil from polypropylene plastic waste.

\begin{tabular}{|c|c|c|c|c|}
\hline & $\begin{array}{c}\text { No } \\
\text { catalyst }\end{array}$ & $\begin{array}{c}\mathbf{5 \%} \\
\mathbf{M o} / \mathbf{A l}-\mathbf{S i}\end{array}$ & $\begin{array}{c}\mathbf{1 0 \%} \\
\mathbf{M o} / \mathbf{A l}-\mathbf{S i}\end{array}$ & $\begin{array}{c}\text { Diesel } \\
\text { standard }\end{array}$ \\
\hline Color & 0.5 & 0.5 & 0.5 & $<7.5$ \\
\hline $\begin{array}{c}\text { Specific } \\
\text { gravity }\end{array}$ & 0.78 & 0.79 & 0.79 & $0.81-0.87$ \\
\hline $\begin{array}{c}\text { Flash point } \\
\left({ }^{\circ} \mathrm{C}\right)\end{array}$ & 27 & 28 & 29 & $>52$ \\
\hline $\begin{array}{c}\text { Viscosity } \\
(\mathrm{cSt})\end{array}$ & 1.49 & 1.43 & 1.47 & $1.80-4.10$ \\
\hline $\begin{array}{c}\text { Distillation } \\
\left({ }^{\circ} \mathrm{C}\right)\end{array}$ & 285.8 & 251.1 & 279.1 & $<357$ \\
\hline $\begin{array}{c}\text { Cetane } \\
\text { index }\end{array}$ & 60.0 & 48.0 & 42.5 & $>50$ \\
\hline
\end{tabular}

For the carbon composition analysis of the pyrolysis oil by Gas Chromatography-Mass Spectrometry (GCMS) can separate the chemical structures in the oil into 6 groups such as straight chain paraffin, branched chain paraffin, double bonding compounds, triple bonding compounds, alicyclic compounds and aromatic compounds. All pyrolysis oils mainly consisted of double bonding compounds and alicyclic compounds, these were $40 \%$ and $50 \%$ respectively. The pyrolysis of polypropylene plastic waste without catalyst produced the pyrolysis oils containing a complex mixture of $\mathrm{C}_{6}$ $\mathrm{C}_{25}$ organic compounds. For the pyrolysis oils produced from polypropylene plastic waste with the 5\% and $10 \%$ molybdenum modified alumina-silica catalysts consisted of a complex mixture of $\mathrm{C}_{5}-\mathrm{C}_{15}$ organic compounds.

\subsection{Effects of types of raw materials on pyrolysis with $10 \%$ molybdenum modified alumina-silica catalyst}

From the pyrolysis of polypropylene plastic waste, the alumina-silica with $10 \%$ molybdenum catalyst had the greatest pyrolysis oil yield. Therefore, in this part the pyrolysis of polyethylene, polystyrene plastic waste, and used engine oil with $10 \%$ molybdenum modified alumina-silica catalyst were conducted at the same conditions with the previous part in order to investigate the effects of different raw materials on pyrolysis. A drinking water bottle cap was used as a high density polyethylene plastic waste. The polystyrene was collected from a foam food container. The used engine oil (API SN 0W20) was supported by the Thanyaburi Honda Cars Center. The pyrolysis oil created from the different raw materials had the color as illustrated in Figure 5 to 8 . 


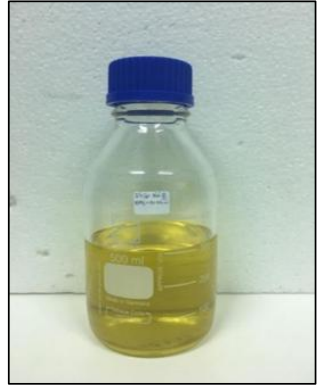

Fig. 5. Liquid from the pyrolysis of polyethylene plastic waste.

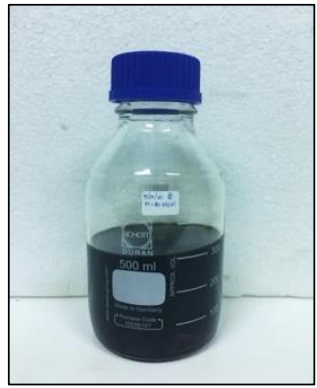

Fig. 6. Liquid from the pyrolysis of polystyrene plastic waste.

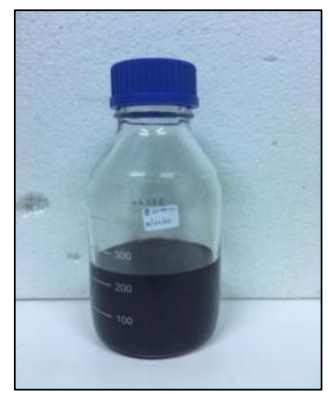

Fig. 7. Liquid from the pyrolysis of used engine oil plastic waste.

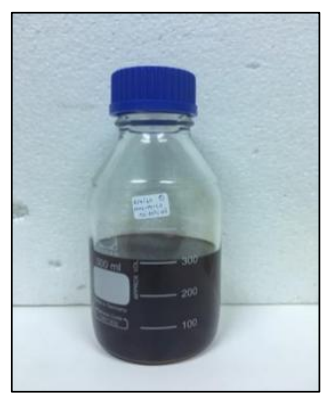

Fig. 8. Liquid from the pyrolysis of mixed polypropylene, polyethylene, polystyrene, and used engine oil.

The products yields are presented in Table 4. The pyrolysis oil obtained from polyethylene, polystyrene and used engine oil were $75.71 \%, 93.13 \%$, and $65.72 \%$ respectively. The result reveals that the different of raw material structure resulted in the pyrolysis product yield [12]. The used engine oil had the lowest pyrolysis oil yield. However, when used engine oil was mixed with polypropylene, polyethylene, and polystyrene plastic waste, the pyrolysis oil yield was increased.
Table 4. The pyrolysis of various raw materials results.

\begin{tabular}{|c|c|c|c|}
\hline \multirow{2}{*}{ Raw materials } & \multicolumn{3}{|c|}{ Yield (\%) } \\
\cline { 2 - 4 } & Gas & $\begin{array}{c}\text { Pyrolysis } \\
\text { oil }\end{array}$ & Solid \\
\hline Polyethylene & 15.58 & 75.71 & 8.71 \\
\hline Polystyrene & 1.19 & 93.13 & 5.68 \\
\hline Used engine oil & 8.14 & 65.72 & 26.14 \\
\hline $\begin{array}{c}\text { Mixed } \\
\text { PP : PE : PS : Oil } \\
(1: 1: 1: 1)\end{array}$ & 16.98 & 78.67 & 4.35 \\
\hline
\end{tabular}

The results of pyrolysis oil properties analysis are shown in Table 5. The color of all substrates met the diesel fuel standard, which were not higher than 7.5. The used engine oil produced the pyrolysis oil having the highest color value up to 3.5 . For specific gravity, the pyrolysis oil from the used engine oil and the mixed raw materials passed the standard criteria of diesel fuel. Only the used engine oil produced the pyrolysis oil passing the viscosity value standard of the diesel fuel. The distillation value at $90 \%$ passed the diesel standard excluding the oil from the polystyrene and the mixed substrates. The foaming occurred while the distillation value measurement of the pyrolysis produced from the foam food container, thus the value could not be determined.

Table 5. The properties of pyrolysis oil from the pyrolysis of different raw materials.

\begin{tabular}{|c|c|c|c|c|}
\hline & $\begin{array}{c}\text { Poly } \\
\text { ethylene }\end{array}$ & $\begin{array}{c}\text { Poly } \\
\text { styrene }\end{array}$ & $\begin{array}{c}\text { Used } \\
\text { engine } \\
\text { oil }\end{array}$ & Mixed \\
\hline Color & 1 & 2.5 & 3.5 & 2 \\
\hline $\begin{array}{c}\text { Specific } \\
\text { gravity }\end{array}$ & 0.79 & 0.94 & 0.81 & 0.83 \\
\hline $\begin{array}{c}\text { Flash point } \\
\left({ }^{\circ} \mathrm{C}\right)\end{array}$ & 35 & 40 & 31 & 28 \\
\hline $\begin{array}{c}\text { Viscosity } \\
(\mathrm{cSt})\end{array}$ & 1.68 & 1.78 & 2.63 & 1.45 \\
\hline $\begin{array}{c}\text { Distillation } \\
\left({ }^{\circ} \mathrm{C}\right)\end{array}$ & 277.5 & $-*$ & 318.1 & $-*$ \\
\hline $\begin{array}{c}\text { Cetane index } \\
\text { (aine }\end{array}$ & 59.5 & $-*$ & 65.5 & $-*$ \\
\hline
\end{tabular}

*Distillation could not be measured, so cetane number were not able to be calculated.

From GC-MS analysis, the main hydrocarbon compound of the pyrolysis oil from the polyethylene and used engine oil was the straight chain paraffin approximately $60 \%$. Other components in the oil from the polyethylene and the used engine oil were the double bonding compounds and the alicyclic compounds. Whereas the polystyrene plastic waste provided the oil 
containing only the aromatic compounds owing to the styrene ring in the polystyrene. These pyrolysis conditions cannot crack the aromatic structure of raw material. For the co-pyrolysis between the used engine oil and the plastic waste namely polypropylene, polyethylene, and polystyrene, it produced the oil consisting of 6 groups of hydrocarbon compounds that are straight chain paraffin, branched chain paraffin, double bonding compounds, triple bonding compounds, alicyclic compounds and aromatic compounds.

\section{Conclusion}

The pyrolysis process of polypropylene plastic waste with and without the molybdenum modified aluminasilica catalysts produced over $80 \%$ yield of pyrolysis oil. The increasing molybdenum content resulted in the enhancing amount of pyrolysis oil. The $10 \%$ molybdenum on alumina-silica catalyst presented the highest yield of pyrolysis oil at $86.63 \%$. The carbon compounds in the pyrolysis oil were mostly double bonding compounds and alicyclic compounds. The use of molybdenum modified alumina-silica catalyst can decompose the polypropylene plastic waste structure to shorter chain carbon compound comparing to the pyrolysis process without the catalyst. The product yields were different when the different sorts of raw materials were applied. Polystyrene presented the highest pyrolysis oil yield, but the oil properties did not qualify the diesel standard. The used engine oil provided the pyrolysis oil qualifying the standard of color, specific gravity, viscosity, distillation, and cetane index despite the lowest pyrolysis oil yield.

The authors would like to acknowledge the Rajamangala University of Technology Thanyaburi (RMUTT) annual government statement of expenditure in 2018 for the financial support. The Energy from Waste for Sustainable Environment Research group at Chemical and Materials Engineering department, RMUTT is also grateful for the instrumental and laboratory supports.

\section{References}

1. S. Sukganta, P. Srichamni, P. Fuengauksorn, L. Komkoontod, W. Kullasiri, P. Kreablumyai, J. Mookprom, S. Niyomthong, Municipal solid waste situation in Thailand in 2017 (Polution Control Department, Thailand, 2018)

2. K. Tanakwang, N. Tangtinchai, Overview on Municipal solid waste management in Thailand (Polution Control Department, Thailand, 2013)

3. I. Macro, B.M. Cabellero, A. Lopez, M.F. Laresgoiti, A. Torres, M.J. Chomon, J. Anal. Appl. Pyrol. 85, 384-391 (2009)

4. T. Kan, V. Strezov, T.J. Evans, Renew. Sust. Energ. Rev. 57, 1126-1140 (2016)

5. M.S. Hossain, M.R. Islam, M.S. Rahman, M.A. Kader, H. Haniu, Energy. Proced. 110, 453-458 (2017)

6. F. Abnisa, W. Daud, Energy. Convers. Manag. 87, 71-85 (2014)

7. P. Pan, C. Hu, W. Yang, Y. Li, L. Dong, L. Zhu, D. Tong, R. Qing, Y. Fan, Bioresource. Technol. 101, 4593-4599 (2010)

8. R. Miandad, M. Rehan, Abdul-Sattar, Nizami, M.A. Barakat, I.M. Ismail, Recycling of solid waste for biofuels and bio-chemicals (Springer Science and Business Media, Singapore, 2016)

9. T. Chanchuey, C. Autthanit, B. Jongsomjit, J. Chem-ny. 2016, 1-8 (2016)

10. N. Tungsupanich, Characteristics and quality of diesel fuel (Thai Department of Energy Business, Thailand, 2015)

11. M.Z.H. Khan, M. Sultana, M.R. Al-Mamun, M.R. Hasan, J. Environ. Public. Health. 2016, 1-6 (2016)

12. N. Phetyim, S. Pivsa-Art, Energies 11, 1-11 (2018). 